\title{
PENGARUH PENGELUARAN PEMERINTAH DAN INVESTASI TERHADAP PERTUMBUHAN EKONOMI DAN TINGKAT KEMISKINAN DI KABUPATEN/KOTA PROVINSI BALI
}

\author{
Nengah Rai Narka Suda Pratama ${ }^{1}$ \\ Made Suyana Utama ${ }^{2}$ \\ ${ }^{1,2}$ Fakultas Ekonomi dan Bisnis Universitas Udayana (Unud), Bali, Indonesia \\ Email:rai.narka97@gmail.com/ Telp.081529416410
}

\begin{abstract}
ABSTRAK
Pembangunan ekonomi suatu daerah pada hakekatnya merupakan suatu rangkaian kegiatan yang dilaksanakan secara sadar dan terus menerus untuk mewujudkan keadaan yang lebih baik secara bersama-sama dan berkesinambungan. Beberapa faktor-faktor yang menjadi penyebab turunnya tingkat kemiskinan adalah pengeluaran pemerintah, investasi, dan pertumbuhan ekonomi. Dengan melihat penurunan tingkat kemiskinan di Provinsi Bali maka peneliti ingin melakukan penelitian tentang pengaruh pengeluaran pemerintah dan investasi terhadap pertumbuhan ekonomi dan tingkat kemiskinan di Kabupaten/Kota Provinsi Bali. Pengumpulan data melalui dokumen yang terdapat di BPS. Teknik analisis menggunakan analisis jalur. Hasil analisis menunjukkan pengeluaran pemerintah dan investasi memiliki pengaruh langsung positif dan signifikan terhadap pertumbuhan ekonomi. Pengeluaran pemerintah memiliki pengaruh langsung negatif dan signifikan terhadap tingkat kemiskinan. Investasi memiliki pengaruh langsung positif namun tidak signifikan terhadap tingkat kemiskinan dan pertumbuhan ekonomi memiliki pengaruh langsung positif dan signifikan terhadap tingkat kemiskinan. Pengeluaran pemerintah dan investasi tidak berpengaruh secara tidak langsung terhadap tingkat kemiskinan melalui pertumbuhan ekonomi.
\end{abstract}

Kata kunci : pengeluaran pemerintah, investasi, pertumbuhan ekonomi, tingkat kemiskinan.

\begin{abstract}
The economic development of region is series of activities carried out consciously and continuously to realize better and more shared situation. Some of factors that cause decline in poverty levels are government spending, investment, economic growth. By looking at the decline in poverty rates in Bali, the researchers want to conduct research on the effects of government spending and investment on economic growth and poverty levels. Data collection through BPS. Path analysis was used. The results of the analysis show that government spending and investment have a positive and significant direct influence on economic growth. Government expenditures have a negative and significant direct influence on poverty levels. Investment has a positive but not significant direct influence on poverty levels and economic growth has a positive and significant direct influence on poverty levels. Government spending and investment do not have an indirect effect on the level of poverty through economic growth.
\end{abstract}

Keywords: government expenditure, investment, economic growth, poverty level. 


\section{PENDAHULUAN}

Keberhasilan pembangunan yang dilaksanakan oleh sebuah negara termasuk Negara Indonesia dapat dilihat dari kondisi kesejahteraan masyarakatnya (Marhaeni dkk., 2014). Persoalan kemiskinan merupakan salah satu target kebijakan pembangunan di setiap negara agar kesenjangan pendapatan menjadi semakin kecil. Kemiskinan merupakan masalah dalam pembangunan yang bersifat multidimensi karena untuk menanggulangi kemiskinan tersebut masalah yang dihadapi tidak terbatas pada hal-hal yang menyangkut hubungan sebab akibat timbulnya kemiskinan tetapi juga melibatkan preferensi, nilai dan politik (Purnama, 2016). Pengentasan kemiskinan telah menjadi tujuan pembangunan yang fundamental dan menjadi sebuah alat ukur untuk menilai efektivitas pelaksanaan berbagai jenis program pembangunan.

Pembangunan ekonomi suatu daerah pada hakekatnya merupakan suatu rangkaian kegiatan yang dilaksanakan secara sadar dan terus menerus untuk mewujudkan keadaan yang lebih baik secara bersama-sama dan berkesinambungan. Dalam kerangka itu, pembangunan ekonomi juga untuk memacu pemerataan pembangunan dan hasil-hasilnya dalam rangka meningkatkan kesejahteraan rakyat secara adil dan merata. Pembangunan daerah merupakan suatu proses pemerintah daerah dan masyarakatnya yang dapat mengelola sumber daya atau potensi yang ada di daerahnya masing-masing, dan membentuk kerjasama dengan sektor swasta sehingga akan menciptakan lapangan pekerjaan baru dan dapat merangsang perkembangan dalam melakukan kegiatan ekonomi atau pertumbuhan ekonomi dalam wilayah tersebut. 
Adanya pertumbuhan ekonomi yang tinggi berasal daripengeluaran pemerintahyang tinggi pula, maka disinilah peran otonomi daerah, yang dapat memperdayakan potensi daerahnya masing-masing. Kebebasan pemerintah daerah dalam hal merencanakan keuangan daerah dan membuat kebijakan yang dapat berpengaruh terhadap kemajuan daerah dan untuk menunjang kemajuan daerah, Pemerintah daerah berhak mengalokasikan anggaran belanja daerah yang dimaksudkan untuk memenuhi kebutuhan publik akan sarana dan prasarana umum yang di perlukan.

Dengan adanya otonomi daerah, pemerintah daerah diharapkan mampu menggali secara optimal sumber-sumber keuangan, mengelola, dan menggunakan keuangannya sendiri untuk membiayai penyelenggaraan pemerintahan sehingga dapat memungkinkan terciptanya kesejahteraan masyarakat yang sangat erat kaitannya dengan kemiskinan. Masalah kemiskinan merupakan tantangan pembangunan yang bersifat multidimensional dan merupakan bagian yang selalu muncul dalam kehidupan masyarakat pada umumnya

Dalam pelaksanaan otonomi daerah, penanggulangan kemiskinan menjadi perhatian utama pembangunan nasional dan daerah, terutama sejak diberlakukannya undang-undang tentang pemerintahan daerah. Hal tersebut seharusnya dijadikan momentum dan peluang untuk mewujudkan desentralisasi pembangunan yang sensitif terhadap persoalan lokal. Berarti memecahkan masalah kemiskinan secara tidak langsung memecahkan banyak persoalan sosial yang dihadapi oleh pemerintah daerah. Dengan desentralisasi fiskal, pemerintah daerah kini memiliki kewenangan yang besar untuk merencanakan, merumuskan, 
dan melaksanakan kebijakan serta program pembangunan yang bisa disesuaikan dengan kebutuhan setempat, dengan tujuan dapat menurunkan jumlah kemiskinan (Scott, 2002). Salah satu kunci yang harus diperhatikan dalam desentralisasi adalah bahwa pemerintah daerah harus lebih responsif terhadap kebutuhan penduduknya. Desentralisasi fiskal dalam pelaksanaannya masih mengalami berbagai kendala di daerah sehingga diperlukan evaluasi agar dapat mengetahui sejauhmana kebijakan desentralisasi fiskal mampu meningkatkan kesejahteraan masyarakat dan mengurangi kemiskinan pada suatu daerah.

Program pengentasan kemiskinan dewasa ini telah banyak dilakukan oleh pemerintah melalui peran instansi terkait, namun jumlah masyarakat miskin belum dapat dihapuskan seratus persen. Hal ini ditunjukkan dari data bahwa jumlah masyarakat yang masih tergolong kurang mampu tetap ada di setiap kabupaten/kota di Provinsi Bali (Yuliarmi, 2014). Penurunan tingkat kemiskinan di Provinsi Bali tidak terlepas dari upaya pengentasan kemiskinan oleh pemerintah pusat maupun daerah dalam bentuk program-program pro-poor. Namun demikian, masih eksis-nya permasalahan kemiskinan di Bali mencerminkan masih diperlukannya formulasi kebijakan yang lebih efektif sehingga mampu mengatasi permasalahan kemiskinan secara menyeluruh (Dariwardani, 2014)

Salah satu strategi atau upaya pengentasan kemiskinan adalah adanya pertumbuhan ekonomi. Pertumbuhan ekonomi merupakan indikator untuk melihat keberhasilan pembangunan dan merupakan syarat bagi pengurangan tingkat 
kemiskinan. Syaratnya adalah hasil dari pertumbuhan ekonomi tersebut dapat menyebar disetiap golongan masyarakat, termasuk di golongan penduduk miskin.

Indikator pertumbuhan ekonomi tidak hanya mengukur tingkat pertumbuhan output dalam suatu perekonomian, karena pertumbuhan ekonomi juga memberikan indikasi tentang sejauh mana aktivitas perekonomian yang terjadi pada suatu periode tertentu telah menghasilkan peningkatan pendapatan bagi masyarakat. Upaya pengentasan kemiskinan juga dilakukan pada kabupaten dan kota di Provinsi Bali. Beberapa faktor-faktor yang menjadi penyebab turunnya tingkat kemiskinan adalah pertumbuhan ekonomi, investasi, dan pengeluaran pemerintah yang memiliki hubungan yang positif terhadap peningkatan kesejahteraan masyarakat.

Tabel 1.

Tingkat Kemiskinan Kabupaten/Kota di Provinsi Bali Tahun 2011-2017

\begin{tabular}{lccccccc}
\hline \multicolumn{1}{c}{ Kabupaten/Kota } & $\mathbf{2 0 1 1}$ & $\mathbf{2 0 1 2}$ & $\mathbf{2 0 1 3}$ & $\mathbf{2 0 1 4}$ & $\mathbf{2 0 1 5}$ & $\mathbf{2 0 1 6}$ & $\mathbf{2 0 1 7}$ \\
\hline Jembrana & 6.56 & 5.74 & 5.56 & 5.83 & 5.84 & 5.33 & 5.38 \\
Tabanan & 5.62 & 4.90 & 5.21 & 5.61 & 5.52 & 5.00 & 4.92 \\
Badung & 2.62 & 2.16 & 2.46 & 2.54 & 2.33 & 2.06 & 2.06 \\
Gianyar & 5.40 & 4.69 & 4.27 & 4.57 & 4.61 & 4.44 & 4.46 \\
Klungkung & 6.10 & 5.37 & 7.01 & 7.01 & 6.91 & 6.35 & 6.29 \\
Bangli & 5.16 & 4.52 & 5.45 & 5.86 & 5.73 & 5.22 & 5.23 \\
Karangasem & 6.43 & 5.63 & 6.88 & 7.30 & 7.44 & 6.61 & 6.55 \\
Buleleng & 5.93 & 5.19 & 6.31 & 6.79 & 6.74 & 5.79 & 5.74 \\
Denpasar & 1.79 & 1.52 & 2.07 & 2.21 & 2.39 & 2.15 & 2.27 \\
\hline Provinsi Bali & $\mathbf{4 . 5 9}$ & $\mathbf{3 . 9 5}$ & $\mathbf{4 . 4 9}$ & $\mathbf{4 . 7 6}$ & $\mathbf{4 . 7 4}$ & $\mathbf{4 . 2 5}$ & $\mathbf{4 . 2 5}$ \\
\hline
\end{tabular}

Sumber: BPS Provinsi Bali, 2018

Dalam Tabel 1 Kabupaten yang memiliki tingkat kemiskinan paling tinggi yaitu Kabupaten Karangasem sebesar 6,55 persen pada tahun 2017, berbanding 
jauh dengan Kabupaten Badung yang tingkat kemiskinan sebesar 2,06 persen pada tahun 2017. Kabupaten Badung dan Kota Denpasar memiliki tingkat kemiskinanpaling kecil, dibandingkan dengan Kabupaten Klungkung, Bangli, Buleleng, Tabanan, Jembrana, dan Gianyar.

Menurut Mukhopadhay dan Fredericks (dalam Arsyad, 2010:300) kebijakan pemerintah belum berhasil memecahkan persoalan kelompok ekonomi di tingkat bawah. Selain itu, kebijakan dalam negeri seringkali tidak terlepas dengan kondisi di luar negeri yang secara tidak langsung mempengaruhi kebijakan dalam negeri, antara lain dari segi pendanaan pembangunan. Oleh karena itu, kemiskinan di samping merupakan masalah yang muncul dalam masyarakat, sehingga diperlukannya perbaikan akses terhadap konsumsi pelayanan sosial seperti pendidikan, kesehatan dan gizi yang merupakan alat kebijakan penting dalam strategi pemerintah secara keseluruhan untuk mengurangi tingkat kemiskinan dan memperbaiki kesejahteraan penduduk di Provinsi Bali.

Penurunan tingkat kemiskinan pada kabupaten/kota di Provinsi Bali disebabkan adanya investasi, baik itu dalam negeri maupun luar negeri. Investasi adalah mobilisasi sumber daya untuk menciptakan atau menambah kapasitas produksi/pendapatan di masa yang akan datang. Apabila semua tenaga kerja berkualitas terlibat aktif dalam perekonomian, akan meningkatkan output barang dan jasa, yang pada akhirnya mendorong pertumbuhan ekonomi. Investasi merupakan penghubung yang kuat untuk pertumbuhan ekonomi dan pengurangan kemiskinan (Ocaya, Ruranga, \& Kaberuka, 2012). Pertumbuhan ekonomi, akan menciptakan investasi, membuka lapangan kerja, menyerap angkatan kerja, yang 
pada gilirannya akan menurunkan tingkat kemiskinan (Seran, 2017). Menurut Harrod-Domar, bahwa investasi merupakan kunci utama dalam pertumbuhan ekonomi suatu daerah. Semakin meningkatya pertumbuhan ekonomi pada suatu daerah, maka semakin tinggi pula investasi suatu daerah, semakin tingginya investasi, pengangguran akan menurun, apabila tingkat pengangguran rendah maka akan berbanding lurus terhadap tingkat kemiskinan (Fosu, 2010)

Upaya penanggulangan kemiskinan juga tidak lepas dari jumlah pengeluaran pemerintah yang dikeluarkan oleh pemerintah daerah. Pengeluaran pemerintah terus naik dari tahun ke tahun dengan harapan akan dapat meningkatkan kesejahteraan masyarakat dan tingkat kemiskinan. Pengeluaran pemerintah juga tidak hanya melihat jumlahnya saja tapi juga melihat ketepatan sasaran dalam pengeluaran pemerintah (Osinubi, 2005). Ikeji (2011) menyatakan bahwa desentralisasi fiskal akan merangsang pertumbuhan dan perkembangan ekonomi di sebuah daerah. Pemerintah daerah diharapkan mampu memajukan pembangunan sosial ekonomi bagi penduduk setempat (Akudugu, 2012). Menurut Cooray (2009) pemerintah daerah harus dapat memiliki tata pemerintahan yang baik agar dapat meningkatkan pertumbuhan ekonomi. Salah satu potensi dampak positif dari penerapan desentralisasi fiskal Indonesia adalah berkembangnya kompetisi antar pemerintah daerah dalam upaya mensejahterakan masyarakatnya (Al Husna \& Yudhistira, 2017)

Pemberian otonomi daerah berpengaruh terhadap pertumbuhan ekonomi suatu daerah karena memberikan kebebasan kepada pemerintah daerah untuk membuat rencana keuangannya sendiri dan membuat kebijakan-kebijakan yang 
dapat mendorong pemerintah daerah untuk melakukan pembangunan ekonomi dengan mengelola sumber daya yang ada. Adanya pertumbuhan ekonomi merupakan salah satu indikator untuk menilai tingkat kemajuan pembangunan dan merupakan salah satu dampak nyata atas keberhasilan dari beberapa kebijakan ekonomi yang diterapkan pada waktu sebelumnya (Budhi, 2013)

Pertumbuhan ekonomi yang tinggi juga mencerminkan semakin besarnya kebutuhan layanan jasa pemerintah, sehingga dibutuhkan anggaran pemerintah yang semakin besar pula. Pendapatan per kapita berkontribusi terhadap PAD sehingga akan meningkatkan pengeluaran pemerintah. Pendapatan perkapita dapat diartikan sebagai jumlah dari nilai suatu barang dan jasa rata-rata yang tersedia bagi penduduk suatu negara pada suatu periode tertentu. Besarnya pendapatan perkapita sering digunakan sebagai pembanding tingkat kemakmuran di berbagai daerah (Norton, 2002). Dengan adanya desentralisasi fiskal dapat mendorong pendapatan perkapita di daerah sehingga dapat mengurangi tingkat keimiskinan (Yushkov, 2015)

Upaya penanggulangan kemiskinan di Provinsi Bali telah dilaksanakan dengan berbagai program dari tahun delapan puluhan, oleh berbagai sektor dan dengan kriteria sasaran yang berbeda-beda. Dengan demikian pelaksanaan paket kegiatannya berjalan mengedepankan konsep sektoral, sehingga tidak terintegrasi, bersinergi dan terkoordinasi. Dengan pemberlakuan Undang-Undang Nomor 22 Tahun 1999 tentang Pemerintah Daerah yang telah disempurnakan dengan dikeluarkan dan diberlakukan Undang-Undang Nomor 32 Tahun 2004, 
merupakan peluang bagi setiap daerah untuk dapat memperbaiki daerahnya masing-masing.

Pengeluaran pemerintah bertujuan untuk meningkatkan kapasitas produksi dalam proyek-proyek yang mengacu pada pertumbuhan ekonomi, pemerataan pendapatan, peningkatan kesejahteraan, dan program yang menyentuh langsung kawasan yang terbelakang. Peran aktif pemerintah daerah diharapkan berperan aktif dalam mengelola dan mengembangkan sektor publik dalam upaya meningkatkan pertumbuhan ekonomi daerah.Pengeluaran pemerintah merupakan seperangkat produk yang dihasilkan yang memuat pilihan atau keputusan yang dibuat oleh pemerintah untuk menyediakan barang-barang publik dan pelayanan kepada masyarakat. Upaya penanggulangan kemiskinan juga tidak lepas dari jumlah pengeluaran pemerintah yang dikeluarkan oleh pemerintah daerah. Pengeluaran pemerintah terus naik dari tahun ke tahun dengan harapan akan dapat meningkatkan kesejahteraan masyarakat dan menurunkan angka kemiskinan. Pengeluaran pemerintah juga tidak hanya melihat jumlahnya saja tapi juga melihat ketepatan sasaran dalam pengeluaran pemerintah. (De Fina, 2002)

Pendapatan per kapita berkontribusi terhadap PAD sehingga akan meningkatkan pengeluaran pemerintah. Pendapatan perkapita dapat diartikan sebagai jumlah dari nilai suatu barang dan jasa rata-rata yang tersedia bagi penduduk suatu negara pada suatu periode tertentu. Besarnya pendapatan perkapita sering digunakan sebagai pembanding tingkat kemakmuran di berbagai daerah (Norton, 2002). Pertumbuhan ekonomi akan mengurangi kemiskinan apabila dibarengi dengan pengurangan kesenjangan atau ketimpangan pendapatan. 
Penurunan kemiskinan dapat lebih cepat jika penduduk miskin mendapat kesempatan untuk berpartisipasi dalam pertumbuhan. Menurut growth model dari Rostow menyatakan bahwa memperbesar kue pembangunan terlebih dahulu kemudian di distribusikan. (Sarungu, 2013)

Berdasarkan hal tersebut pemerintah daerah terlebih dahulu meningkatkan pertumbuhan ekonomi yang kemudian didistribusi atau memberikan dampak terhadap daerah-daerah dalam tingkat kesejahtraan dan menurunkan tingkat kemiskinan yang terdapat di daerah. Hal ini didukung oleh penelitian Balisacan et al. (2003).

\section{METODE PENELITIAN}

Penelitian ini termasuk dalam jenis penelitian kuantitatif. Penelitian ini dilakukan dengan menggunakan paradigma asosiatif. Peneliti akan melakukan analisis untuk mengetahui hubungan beberapa variabel yaitu pengaruh langsung variabel pengeluaran pemerintah dan investasi terhadap tingkat kemiskinan, pengaruh langsung pengeluaran pemerintah dan investasi terhadap pertumbuhan ekonomi serta pengaruh tidak langsung dari pengeluaran pemerintah dan investasi terhadap tingkat kemiskinan melalui pertumbuhan ekonomi di kabupaten/kota Provinsi Bali selama periode 2011-2017. 


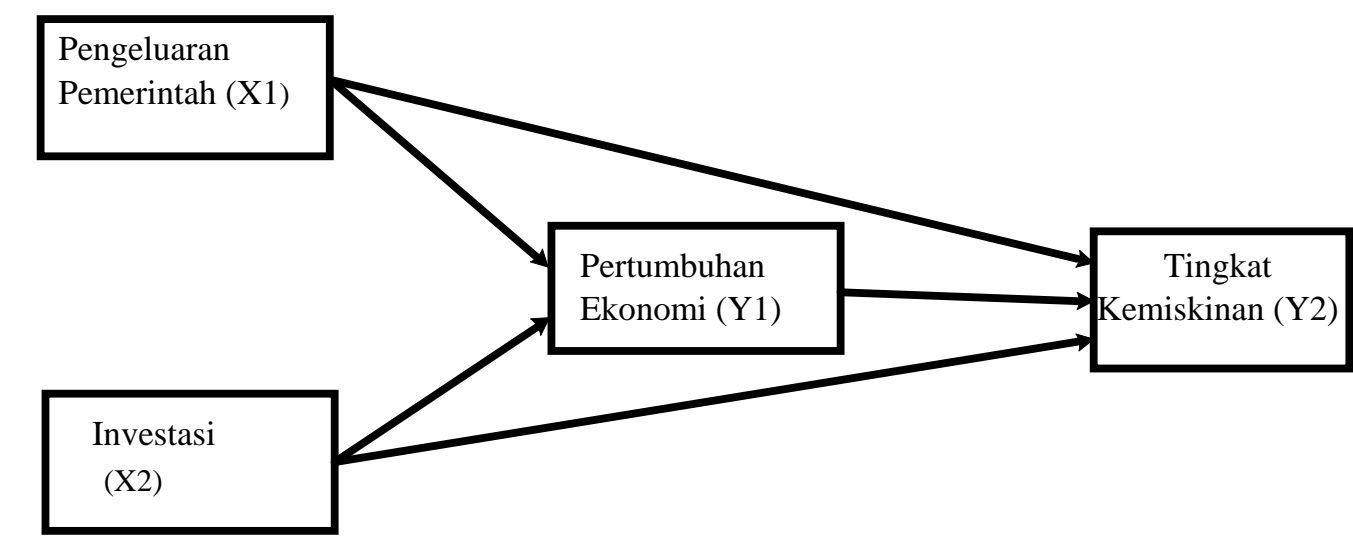

\section{Gambar 1 Kerangka Konseptual Penelitian \\ Pengaruh Pengeluaran Pemerintah Dan Investasi Terhadap \\ Pertumbuhan Ekonomi Dan Tingkat Kemiskinan Di Kabupaten/Kota Provinsi Bali}

Berdasarkan pokok permasalahan, tujuan penelitian, landasan teori maka hipotesis penelitian yang diajukan pada penelitian ini sebagai berikut 1) Pengeluaran Pemerintah dan Investasi berpengaruh positif dan signifikan terhadap Pertumbuhan Ekonomi di Kabupaten/Kota Provinsi Bali. 2) Pengeluaran Pemerintah, Investasi dan Pertumbuhan Ekonomi berpengaruh negatif dan signifikan terhadap Tingkat Kemiskinan di Kabupaten/Kota Provinsi Bali. 3) Pengeluaran Pemerintah dan Investasi berpengaruh secara tidak langsung terhadap Tingkat Kemiskinan melalui Pertumbuhan Ekonomi Kabupaten/Kota Provinsi Bali.

Lokasi penelitian dilakukan Provinsi Bali yang dibagi menjadi 9 kabupaten/kota dengan menggunakan data-data yang dikeluarkan Badan Pusat Statistik yang terkait dengan obyek-obyek penelitian. Objek penelitian ini adalah pengeluaran pemerintah, investasi, pertumbuhan ekonomi dan tingkat kemiskinan pada kabupaten/kota di Provinsi Bali. 
Teknik analisis data yang digunakan untuk memecahkan permasalahan dalam penelitian ini adalah teknik analisis kuantitatif dengan bantuan program Eviews 9 berupa data panel. Penelitian ini diajukan sebagai penelitian empiris untuk mengetahui pengaruh pengeluaran pemerintah dan investasi terhadap pertumbuhan ekonomi dan tingkat kemiskinan pada kabupaten/kota di Provinsi Bali. Teknik analisis data yang digunakan adalah teknik analisis jalur (path analysis). Tujuan dari analisis data panel menentukan apakah model yang digunakan menganut common effect, fixed effect dan random effect.

Pertama yang harus dilakukan adalah melakukan uji $\mathrm{F}$ untuk memilih model mana yang terbaik di antara ketiga model tersebut dilakukan uji Chow dan uji Hausman. Uji Chow dilakukan untuk menguji antara model common effect dan fixed effect, sedangkan uji Hausman dilakukan untuk menguji apakah data dianalisis dengan menggunakan fixed effect dan random effect, pengujian tersebut dilakukan dengan Eviews9. Pedoman yang akan digunakan dalam pengambilan kesimpulan uji Chow adalah sebagai berikut: Jika hasil uji spesifikasi menunjukkan probabilitas Chi-square lebih dari 0,05 maka model yang dipilih adalah common effect. Sebaliknya, apabila probabilitas Chi-square kurang dari 0,05 maka model yang sebaiknya dipakai adalah fixed effect, dan dilanjutkan dengan uji Hausman untuk memilih apakah menggunakan model fixed effect atau random effect.

Selanjutnya untuk melakukan Hausman Test, data juga diregresikan dengan model random effect, kemudian dibandingkan antara fixed effect dan random effect dengan membuat hipotesis. Pedoman yang akan digunakan dalam 
pengambilan kesimpulan uji Hausman adalah sebagai berikut: Jika nilai probability Cross-section random lebih dari 0,05 maka model yang dipilih adalah random effect. Sebaliknya, apabila probabilitas Chi-square kurang dari 0,05 maka model yang sebaiknya dipakai adalah fixed effect.

\section{HASIL PENELITIAN DAN PEMBAHASAN}

Statistik deskriptif yang digunakan dalam penelitian ini adalah rata-rata (mean), standar deviasi (standard deviation), maksimum, dan minimum. Statistik deskriptif data penelitian ini ditujukkan pada Tabel 2.

Tabel 2.

Statistik Deskriptif Data Penelitian

\begin{tabular}{lcccc}
\hline & PP $(\mathrm{X} 1)$ & INVESTASI $(\mathrm{X} 2)$ & PE (Y1) & KEMISKINAN (Y2) \\
\hline \hline Mean & 12.618 & 14.966 & 10.414 & 1.522 \\
Maximum & 13.015 & 16.413 & 11.306 & 2.006 \\
Minimum & 12.202 & 13.909 & 9.548 & 0.418 \\
Std. Dev. & 0.217 & 0.819 & 0.362 & 0.427 \\
Observations & 63 & 63 & 63 & 63 \\
\hline
\end{tabular}

Sumber: data diolah

Berdasarkan Tabel 2 variabel Pengeluaran Pemerintah (PP), Investasi, Pertumbuhan Ekonomi (PE), dan Kemiskinan. Dalam penelitian ini menunjukkan bahwa Pengeluaran Pemerintah mempunyai nilai minimum sebesar 12.202, terbesar sebesar 13.015 dengan rata-rata 12.618 dan standar deviasinya sebsesar 0,217. Variabel Investasi mempunyai nilai rata-rata 14.966, nilai terbesar 16.413, nilai minimum sebesar 13.909 dengan standar deviasinya 0.819 .

Variabel Pertumbuhan Ekonomi merupakan laju pertumbuhan PDRB Per Kapita dari tahun ke tahun mempunyai nilai minimum sebsesar 9.548, terbesar sebsesar 11.306, dengan rata-rata 10.414, dan standar deviasinya 0.362. 
Variabel tingkat kemiskinan merupakan persentase penduduk yang hidup dibawah garis kemiskinan mempunyai nilai rata-rata 1.522 , tingkat kemiskinan tertinggi sebesar 2.006 dengan tingkat kemiskinan terendah sebesar 0.418 dan standar deviasinya sebesar 0.427 .

Hasil penentuan kelayakan persamaan model data panel, diperlukan uji Chow dan uji Hausman.

Hasil pengujian ditunjukkan seperti pada Tabel 3.

Tabel 3.

\section{Hasil Uji Chow}

\begin{tabular}{lrrr}
\hline \hline Effects Test & Statistic & d.f. & Prob. \\
\hline \hline Cross-section F & 68.020 & $(8,51)$ & 0.000 \\
Cross-section Chi-square & 154.792 & 8 & 0.000 \\
\hline \hline
\end{tabular}

Sumber : data diolah

Berdasarkan Tabel 3 diperoleh nilai prob. Sebesar $0.000<0,05$ maka $\mathrm{H}_{0}$ ditolak dan $\mathrm{H}_{1}$ diterima, artinya berdasarkan hasil tersebut, maka model yang dipilih adalah fixed effect model.

Uji Hausman dilakukan untuk menguji apakah model yang digunakan menganut fixed effect atau random effect. Hasil pengujian ditunjukkan pada Tabel 4.

Tabel 4.

\section{Hasil Uji Hausman}

\begin{tabular}{lccc}
\hline \hline Test Summary & Chi-Sq. Statistic & Chi-Sq. d.f. & Prob. \\
\hline \hline Cross-section random & 8.0910 & 3 & 0.044 \\
\hline \hline Sumber: data diolah & & &
\end{tabular}


Berdasarkan Tabel 4.10 diperoleh nilai prob. Sebesar $0.044<0,05$ maka $\mathrm{H}_{0}$ ditolak dan $\mathrm{H}_{1}$ diterima artinya berdasarkan hasil tersebut, maka model yang dipilih adalah fixed effect model. Berdasarkan hasil tersebut, model yang dipilih adalah fixed effect model.

Hasil Pengujian Koefisien Analisis Jalur

Pemeriksaan Validitas Model, berdasarkan hasil perhitungan koefisien determinasi total $R_{m}^{2}$ : 0.989 yang maka diperoleh bahwa keragaman data yang dapat dijelaskan oleh model adalah sebesar 98,9 persen atau dengan kata lain informasi yang terkandung dalam data sebesar 98,9 persen dapat dijelaskan oleh model, sedangkan sisanya yaitu 1,1 persen dijelaskan oleh variabel lain yang tidak terdapat dalam model.

Uji Pengaruh Langsung (Path Coefficient), berdasarkan hasil olahan data, pengaruh langsung suatu variabel terhadap variabel lainnya dalam penelitian ini disajikan pada Tabel 5 .

Tabel 5.

Pengaruh Langsung Antar Variabel Penelitian

\begin{tabular}{cccccl}
\hline $\begin{array}{c}\text { Hubungan } \\
\text { Antar } \\
\text { variabel }\end{array}$ & Coefficient & $\begin{array}{c}\text { Std } \\
\text { Error }\end{array}$ & T-statistic & Prob. & \multicolumn{1}{c}{ Keterangan } \\
\hline $\mathrm{X}_{1} \longrightarrow \mathrm{Y}_{1}$ & 0.778 & 0.491 & 2.645 & 0.013 & Positif dan Signifikan \\
$\mathrm{X}_{1} \longrightarrow \mathrm{Y}_{2}$ & -0.378 & 0.250 & -2.973 & 0.004 & Negatif dan Signifikan \\
$\mathrm{X}_{2} \longrightarrow \mathrm{Y}_{1}$ & 0.352 & 0.092 & 1.685 & 0.048 & Positif dan Signifikan \\
$\mathrm{X}_{2} \longrightarrow \mathrm{Y}_{2}$ & 0.017 & 0.042 & 0.216 & 0.414 & Positif namun Tidak \\
& & & & & Signifikan \\
$\mathrm{Y}_{1} \longrightarrow \mathrm{Y}_{2}$ & 0.098 & 0.061 & 1.888 & 0.032 & Positif dan Signifikan \\
\hline
\end{tabular}

Berdasarkan tabel 5, hubungan antar variabel dapat dilihat lebih jelas pada gambar 2 


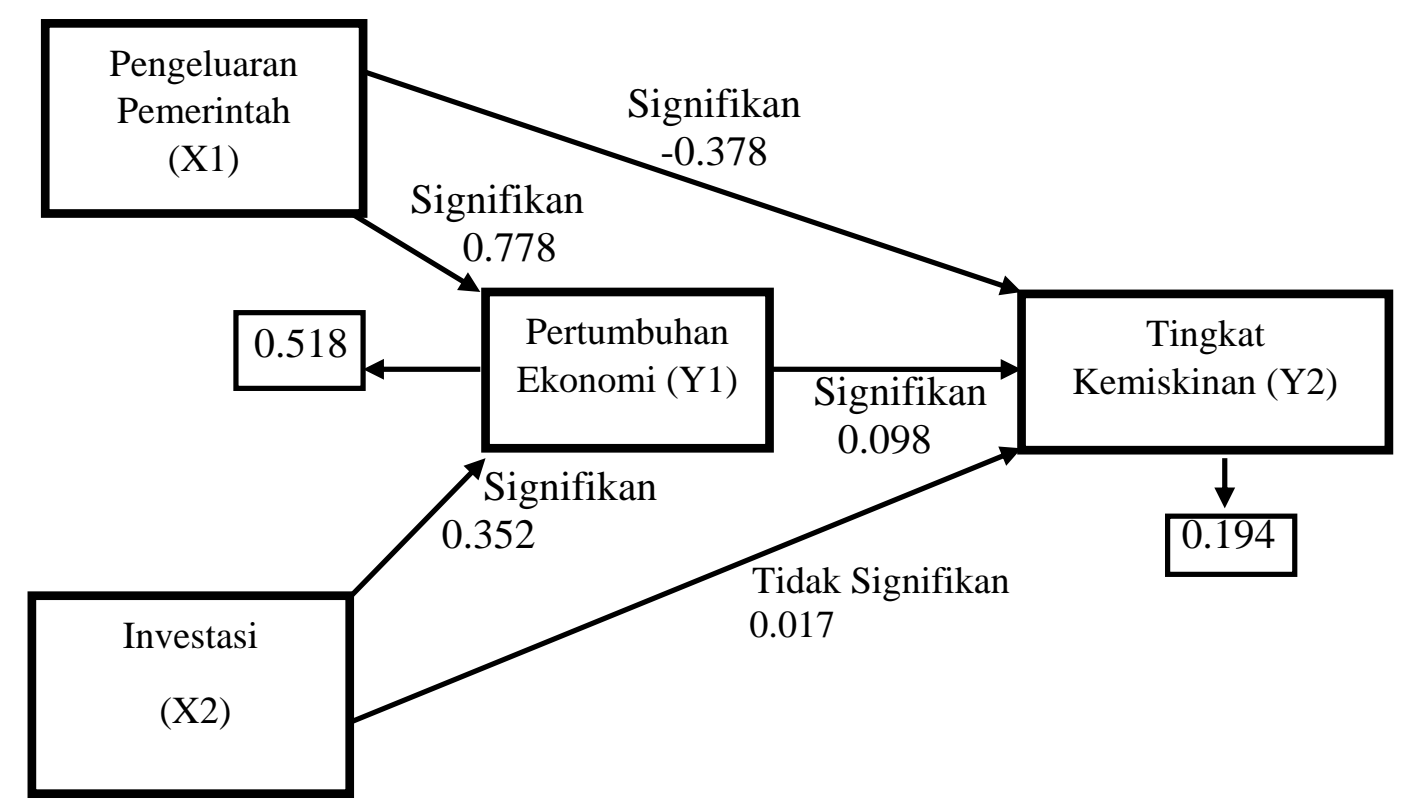

Gambar 2 Koefisien Jalur Hubungan Antarvariabel Penelitian

Berdasarkan Tabel 5, dapat dijelaskan bahwa variabel pengeluaran pemerintah $\left(\mathrm{X}_{1}\right)$ berpengaruh positif terhadap pertumbuhan ekonomi $\left(\mathrm{Y}_{1}\right)$ dengan nilai probabilitas sebesar 0.013 atau kurang dari 5 persen. Variabel pengeluaran pemerintah $\left(\mathrm{X}_{1}\right)$ berpengaruh negatif terhadap tingkat kemiskinan $\left(\mathrm{Y}_{2}\right)$ dengan nilai probabilitas sebesar 0.004 . Variabel investasi $\left(\mathrm{X}_{2}\right)$ berpengaruh positif terhadap pertumbuhan ekonomi $\left(\mathrm{Y}_{1}\right)$ dengan nilai probabilitas sebesar 0.048 . Variabel investasi $\left(\mathrm{X}_{2}\right)$ berpengaruh positif terhadap tingkat kemiskinan $\left(\mathrm{Y}_{2}\right)$ dengan nilai probabilitas sebesar 0.414 . Hal ini berarti investasi tidak berpengaruh terhadap tingkat kemiskinan. Variabel pertumbuhan ekonomi $\left(\mathrm{Y}_{1}\right)$ berpengaruh positif terhadap tingkat kemiskinan $\left(\mathrm{Y}_{2}\right)$ dengan nilai probabilitas sebesar 0.032 . Hubungan antar variabel penelitian secara lengkap juga disajikan pada diagram 
jalur Gambar 2. Berdasarkan gambar 2 apabila dicermati bahwa tidak ada koefisien jalur yang memiliki nilai lebih dari satu, namun varibel pengeluaran memiliki nilai koefisien kurang dari minus satu.

Uji Pengaruh Tidak Langsung (Indirect Effect), pada penelitian ini, uji Sobel digunakan untuk menguji analisis path. Hasil uji Sobel ditujukkan pada Tabel 6.

Tabel 6.

Pengaruh Tidak Langsung (Indirect Effect) Variabel Penelitian

\begin{tabular}{cccccc}
\hline $\begin{array}{c}\text { Hubungan } \\
\text { Antarvariabel }\end{array}$ & $\begin{array}{c}\text { Variabel } \\
\text { Mediasi }\end{array}$ & axb & Sab & $\mathrm{Z}$ & Keterangan \\
\hline $\mathrm{X}_{1} \longrightarrow \mathrm{Y}_{2}$ & $\mathrm{Y}_{1}$ & 0.150 & 0.097 & 1.553 & Tidak Signifikan \\
$\mathrm{X}_{2} \longrightarrow \mathrm{Y}_{2}$ & $\mathrm{Y}_{1}$ & 0.018 & 0.014 & 1.292 & Tidak Signifikan \\
\hline
\end{tabular}

Sumber: data diolah

Berdasarkan Tabel 4.14, menunjukkan bahwa pengaruh tidak langsung variabel pengeluaran pemerintah $\left(\mathrm{X}_{1}\right)$ terhadap tingkat kemiskinan $\left(\mathrm{Y}_{2}\right)$ melalui pertumbuhan ekonomi $\left(\mathrm{Y}_{1}\right)$ memiliki nilai axb sebesar 0.150 lebih kecil dari 1,96. Hal tersebut membuktikan bahwa secara tidak langsung pengeluaran pemerintah $\left(\mathrm{X}_{1}\right)$ melalui pertumbuhan ekonomi $\left(\mathrm{Y}_{1}\right)$ tidak berpengaruh terhadap tingkat kemiskinan. Pengaruh tidak langsung variabel investasi $\left(\mathrm{X}_{2}\right)$ terhadap tingkat kemiskinan $\left(\mathrm{Y}_{2}\right)$ melalui pertumbuhan ekonomi $\left(\mathrm{Y}_{1}\right)$ memiliki nilai axb sebesar 0.018 lebih kecil dari 1,96. Hal tersebut membuktikan bahwa secara tidak langsung variabel investasi $\left(\mathrm{X}_{2}\right)$ tidak berpengaruh terhadap tingkat kemiskinan $\left(\mathrm{Y}_{2}\right)$ melalui pertumbuhan ekonomi $\left(\mathrm{Y}_{1}\right)$ 


\section{PEMBAHASAN}

Berdasarkan hasil analisis yang telah dilakukan, diperoleh pengeluaran pemerintah berpengaruh positif dan signifikan terhadap pertumbuhan ekonomi di Kabupaten/Kota Provinsi Bali. Artinya dengan semakin tinggi pengeluaran pemerintah maka pertumbuhan ekonomi akan semakin meningkat, karena pengeluaran pemerintah merupakan faktor penting dalam meningkatkan pertumbuhan ekonomi. Pengeluaran pemerintah sangat diperlukan oleh suatu daerah untuk tumbuh dan berkembang sesuai dengan potensi daerah masingmasing.

Penelitian ini juga sesuai dengan penelitian yang dilakukan oleh Putra (2017)dimana pengeluaran pemerintah berpengaruh positif terhadap pertumbuhan ekonomi. Tujuan dari pengeluaran pemerintah yang cukup besar adalah pembangunan infrastruktur karena dengan adanya infrastruktur yang memadai dan semakin berkualitas memang sangat diperlukan untuk memacu laju pertumbuhan ekonomi secara optimal, dan dapat menjamin tercapainya kesejahteraan bagi seluruh lapisan masyarakat secara lebih merata.

Berdasarkan hasil analisis yang telah dilakukan, diperoleh investasi berpengaruh positif dan signifikan terhadap pertumbuhan ekonomi di Kabupaten/Kota Provinsi Bali. Artinya adanya hubungan positif antara variabel Investasi terhadap Pertumbuhan Ekonomi (PDRB Per kapita) yang diperoleh dalam penelitian ini, Investasi dapat menjadi tolak ukur bagi keberhasilan dan keberlanjutan pembangunan di masa depan karena dapat menyerap tenaga kerja, 
sehingga dapat membuka kesempatan kerja baru bagi masyarakat yang pada gilirannya akan berdampak terhadap peningkatan pendapatan masyarakat. Hal ini disebabkan karena semakin besar investasi maka akan menyebabkan pertumbuhan ekonomi meningkat. Teori Harrod-Domar menyatakan bahwa pembentukan modal dianggap sebagai pengeluaran yang akan menambah kemampuan suatu perekonomian untuk menghasilkan barang dan atau jasa, maupun sebagai pengeluaran yang akan menambah permintaan efektif seluruh masyarakat. Dimana apabila pada suatu masa tertentu dilakukan sejumlah pembentukan modal, maka pada masa berikutnya perekonomian tersebut mempunyai kemampuan utnuk menghasilkan barang-barang dan atau jasa yang lebih besar sehingga dapat meningkatkan pertumbuhan ekonomi.

Penelitian yang dilakukan Sodik (2007)tentang investasi dan pertumbuhan ekonomi regional di Indonesia menunjukkan bahwa investasi tidak berpengaruh terhadap pertumbuhan ekonomi regional. Penyebab investasi tidak berpengaruh terhadap pertumbuhan ekonomi regional, karena masih rendahnya pelayanan publik, kurangnya kepastian hukum dan berbagai peraturan daerah (perda) yang masih mempersulit investor. Pelayanan publik yang dikeluhkan terutama terkait dengan ketidakpastian biaya dan lamanya waktu berurusan dengan perijinan dan birokrasi. Ini diperparah dengan masih adanya berbagai pungutan resmi maupun liar. Sehingga alasan utama investor masih khawatir untuk melakukan investasi di Indonesia maupun di daerah. Untuk meningkatkan investasi di Kabupaten/Kota Provinsi Bali, pemerintah harus meningkatan pelayan publik yang dapat mempermudah investor untuk dapat berinvestasi di Provinsi Bali serta pemerintah 
juga harus membangun infrastruktur; seperti pembangunan jalan tol, pelabuhan, bandara, satelit, serta peningkatan kapasitas SDM yang seiring waktu akan berpengaruh terhadap pertumbuhan ekonomi masyarakat.

Berdasarkan hasil analisis yang telah dilakukan, diperoleh pengeluaran pemerintah berpengaruh negatif dan signifikan terhadap tingkat kemiskinan di Kabupaten/Kota Provinsi Bali. Artinya bahwa pengeluaran pemerintah merupakan faktor yang penting dalam mengurangi jumlah penduduk miskin yang ada di Kabupaten/Kota Provinsi Bali. Menurut teori Adolf Wagner menyatakan bahwa dalam suatu perekonomian apabila pendapatan per kapita meningkat maka secara relatif pengeluaran pemerintah pun akan meningkat terutama disebabkan karena pemerintah harus mengatur hubungan yang timbul dalam masyarakat seperti: hukum, pendidikan, rekreasi, kebudayaan dan sebagainya. Berkaitan dengan hukum Wagner, dapat dilihat beberapa penyebab semakin meningkatnya pengeluaran pemerintah, yakni meningkatnya fungsi pertahanan keamanan dan ketertiban, meningkatnya fungsi kesejahteraan, meningkatnya fungsi perbankan dan meningkatnya fungsi pembangunan. Pengeluaran pemerintah secara langsung berpengaruh terhadap sektor konsumsi masyarakat atas barang dan jasa. Dengan adanya pengeluaran pemerintah untuk subsidi, tidak hanya menyebabkan masyarakat yang kurang mampu dapat menikmati suatu barang/jasa, namun juga menyebabkan masyarakat yang sudah mampu akan mengkonsumsi produk/jasa lebih banyak lagi.

Penelitian ini telah sesuai dengan penelitian yang dilakukan oleh Jung et al. (2009)dan Anderson (2009)menyatakan bahwa pengeluaran pemerintah 
memegang peranan penting dalam pengentasan kemiskinan. Pengentasan kemiskinan diperlukan kebijakan yang tepat dan terarah terhadap daerah-daerah kantong kemiskinan.Pemerintaah Provinsi Bali dalam upaya pengentasan kemiskinan perlu melaksanakan kebijakan yang dapat diidentifikasi mempunyai pengaruh baik secara langsung maupun tidak langsung terhadap kemiskinan adalah pengeluaran untuk pendidikan, kesehatan, infrastruktur, teknologi, perumahan, subsidi,pemberdayaan masyarakat dan penguatan Usaha Menengah Kecil dan Mikro (UMKM) dengan instrumennya Kredit Usaha Rakyat (KUR).

Pengeluaran pemerintah di Provinsi Bali terpusat di Kabupaten Badung dan Kota Denpasar, sehingga jumlah penduduk miskin yang dekat dengan daerah perkotaan sangat sedikit dibandingkan dengan daerah pedesaan. Daerah pedesaan terutama pada sektor pertanian perlu mandapatkan perhatian yang lebih banyak, karena sektor ini banyak terdapat masyarakat yang berada di bawah garis kemiskinan. Program pemberdayaan masyarakat merupakan salah satu upaya dalam menurunkan angka kemiskinan. Pemberdayaan masyarakat harus ditunjukkan kepada masyarakat miskin, sehingga masyarakat miskin akan lebih produktif, dan memiliki penghasilan yang lebik baik. (Kuncoro, 2004)

Berdasarkan hasil analisis yang telah dilakukan, diperoleh investasi berpengaruh positif namun tidak signifikan terhadap tingkat kemiskinan di Kabupaten/Kota Provinsi Bali. Hal ini berarti tidak sejalan dengan hipotesis penelitian yang menyatakan bahwa investasi berpengaruh negatif terhadap tingkat kemiskinan. Artinya bahwa investasi yang dilakukan oleh pemerintah maupun 
swasta masih belum merata dan tidak menyentuh masyarakat miskin yang ada di setiap Kabupaten/Kota Provinsi Bali.

Hasil penelitian ini sesuai dengan hasil penelitian yang dikemukakan oleh Mustamin \& Nurbayani (2015)yang menyatakan bahwa Adanya hasil yang tidak berpengaruh antara investasi dengan kemiskinan disebabkan pula oleh diduga bahwa kebanyakan investasi yang ada hanya dilakukan oleh kaum menengah ke atas, dan itu hanya berdampak pada kehidupan mereka masing- masing, dan tidak memberikan pengaruh terhadap kehidupan penduduk miskin. Di samping itu, karena adanya investasi yang lebih terkonsentrasi pada pembangunan sektorsektor yang kurang menyerap tenaga kerja, seperti sub sektor kehutanan (logging), industri kimia, dan belanja sekretariat DPRD.

Untuk menurunkan tingkat kemiskinan yang ada disetiap Kabupaten/Kota Provinsi Bali, pemerintah harus memberikan hak penggunaan tanah bagi penduduk miskin. Dengan adanya kepastian dalam kepemilikan tanah merupakan faktor penting untuk meningkatkan investasi dan produktifitas pertanian. Pemberian hak atas tanah juga membuka akses penduduk miskin pada kredit dan pinjaman. Dengan memiliki sertifikat kepemilikan masyarakat dapat meminjam uang, menginvestasikannya dan mendapatkan hasil yang lebih tinggi dari aktifitas yang akan digunakan untuk meningkatkan pendapatannya. Dengan adanya peningkatan investasi maka akan dapat membuka lapangan pekerjaan yang lebih luas, penyerapan tenaga kerja akan lebih banyak. Sehingga dengan adanya penyerapan tenaga kerja akan berdampak pada peningkatan taraf hidup masyarakatnya. 
Berdasarkan hasil analisis yang telah dilakukan, diperoleh pertumbuhan ekonomi berpengaruh positif dan signifikan terhadap tingkat kemiskinan di Kabupaten/Kota Provinsi Bali. Hal ini berarti tidak sejalan dengan hipotesis penelitian yang menyatakan bahwa pertumbuhan ekonomi berpengaruh negatif terhadap tingkat kemiskinan. Artinya bahwa pertumbuhan ekonomi belum mampu mengurangi persentase angka kemiskinan. Hasil penelitian ini sesuai dengan hasil penelitian yang dikemukakan oleh Budhi (2013)yang menyatakan bahwa permasalahan kemiskinan tidak dapat dipecahkan hanya dengan menamatkan pendidikannya dan PDRB per kapita semata yang dengan mengharapkan terjadinya efek menetes kebawah (trickle down effect). Syarat untuk menurunkan angka kemiskinan, yaitu perlu adanya industrialisasi pertanian/perdesaan dan distribusi pendapatan yang tepat, serta akumulasi modal manusia yang relatif cepat. Untuk meningkatkan penghasilan tersebut, terutama yang berasal dari usaha kecil dan menengah, perlu dibangun iklim usaha yang lebih kondusif, yaitu dengan cara membangun lembaga-lembaga pembiayaan mikro yang memberi manfaat pada penduduk miskin. Pertumbuhan ekonomi yang ada di Kabupaten/Kota Provinsi Bali relative stabil dan berdampak positif terhadap jumlah penduduk miskin. Pertumbuhan ekonomi yang proyeksikan dari PDRB per kapita telah dapat menurunkan jumlah penduduk miskin yang ada di Kabupaten/Kota Provinsi Bali. Meskipun jumlah penduduk miskin masih banyak terdapat di daerah pedesaan, namun secara umum pertumbuhan PDRB per kapita yang ada sudah cukup baik dalam hal pengentasan kemiskinan. Mengeksplorasi tantangan pertumbuhan ekonomi yang dihadapi oleh ekonomi yang melimpah 
dalam tenaga kerja dan sumber daya alam dalam ekonomi global yang semakin maju,bahwa penghargaan spesialisasi yang semakin didominasi oleh beberapa negara berkembang yang sangat besar, terutama Cina (Coxhead,2008)

Berdasarkan hasil perhitungan yang telah dilakukan, diperoleh pertumbuhan ekonomi bukan merupakan variabel intervening pengeluaran pemerintah terhadap tingkat kemiskinan di Kabupaten/Kota Provinsi Bali. Hal ini berarti tidak sejalan dengan hipotesis penelitian yang menyatakan bahwa pertumbuhan ekonomi merupakan variabel intervening pengeluaran pemerintah terhadap tingkat kemiskinan. Artinya pengeluaran pemerintah masih belum efektif dalam meningkatkan pertumbuhan ekonomi masyarakatnya yang akan berdampak pada penurunan kemiskinan, karena pengeluaran pemerintah diharapkan mampu meningkatkan investasi dan pertumbuhan ekonomi masyarakatnya. Sehingga secara langsung maupun tidak langsung dapat menurunkan jumlah penduduk miskin yang ada di Kabupaten/Kota Provinsi Bali.

Hasil penelitian ini sesuai dengan hasil penelitian yang dikemukakan oleh Amalia \& Razak (2015) yang menyatakan bahwa pengeluaran pemerintah memiliki efek langsung maupun tidak langsung terhadap penurunan tingkat kemiskinan. Efek langsung muncul dalam bentuk manfaat yang diterima dari pengeluaran pada program kerja dan kesejahteraan. Efek tidak langsung muncul ketika investasi pemerintah di bidang infrastruktur pedesaan, pertanian, kesehatan dan pendidikan masyarakat pedesaan merangsang pertumbuhan pertanian dan non- pertanian yang mengarah ke pekerjaan yang lebih besar dan kesempatan memperoleh penghasilan bagi masyarakat miskin dan bahan makanan yang lebih 
murah. Sehingga hubungan antara pengeluaran pemerintah dan penurunan tingkat kemiskinan kemiskinan berasal dari tiga sumber yaitu pertumbuhan ekonomi, kesempatan kerja dan upah. Peningkatan belanja publik akan meningkatkan permintaan agregat dalam perekonomian. Permintaan terhadap tenaga kerja sebagai akibat dari meningkatnya permintaan agregat menaikkan tingkat produktivitas tenaga kerja. Kesempatan kerja yang lebih tinggi dan produktivitas mengarahkan pada dua jalur. Pertama, menaikkan tingkat upah yang selanjutnya berkontribusi dalam pengurangi kemiskinan dan kedua, percepatan dalam pertumbuhan ekonomi yang dapat menaikkan belanja publik dengan tujuan untuk menurunkan tingkat kemiskinan yang ada di Provinsi Bali.

Berdasarkan hasil perhitungan yang telah dilakukan, diperoleh pertumbuhan ekonomi bukan merupakan variabel intervening investasi terhadap tingkat kemiskinan di Kabupaten/Kota Provinsi Bali. Hal ini berarti tidak sejalan dengan hipotesis penelitian yang menyatakan bahwa pertumbuhan ekonomi merupakan variabel intervening investasi terhadap tingkat kemiskinan. Artinya Lemahnya hubungan antara investasi terhadap kemiskinan melalui pertumbuhan ekonomi menunjukkan adanya dampak bahwa tingginya investasi yang lebih diarahkan untuk meningkatkan pertumbuhan ekonomi, dibandingkan untuk menurunkan kemiskinan dan karena adanya iklim investasi yang tidak kondusif menyebabkan angka kemiskinan di Kabupaten/Kota Provinsi Bali mengalami kecenderungan meningkat. Dalam hal ini investasi yang ada di masih belum optimal dalam meningkatkan pertumbuhan ekonomi masyarakatnya, karena dengan adanya investasi dari swasta maka akan dapat meningkatkan pertumbuhan ekonomi, 
untuk meningkatkan pertumbuhan ekonomi maka perlu adanya upaya untuk mendorong peningkatan investasi yang proporsional dan lebih memihak kepada kepentingan publik sehingga mampu memberikan efek positif terhadap pertumbuhan ekonomi (PDB) dan pengentasan kemiskinan yang ada di daerah.

Hasil penelitian ini sesuai dengan hasil penelitian yang dikemukakan oleh Pateda dkk. (2017) yang menyatakan bahwa investasi diperlukan untuk memenuhi kebutuhan masyarakat, berupa sumber nafkah atau pendapatan untuk membeli barang dan jasa yang diperlukannya

\section{SIMPULAN}

Pengeluaran pemerintah memiliki pengaruh yang negatif dan signifikan terhadap tingkat kemiskinan. Investasi memiliki pengaruh positif namun tidak signifikan terhadap tingkat kemiskinan, sedangkan pertumbuhan ekonomi memiliki pengaruh positif dan signifikan terhadap tingkat kemiskinan Kabupaten/Kota di Provinsi Bali. Artinya pertumbuhan ekonomi merupakan syarat bagi pengurangan kemiskinan. Adanya syarat kecukupannya adalah pertumbuhan tersebut harus efektif mengurangi kemiskinan, pertumbuhan ekonomi hendaklah menyebar di setiap golongan pendapatan, termasuk di golongan penduduk miskin. Pengeluaran pemerintah dan investasi tidak berpengaruh secara tidak langsung terhadap tingkat kemiskinan melalui pertumbuhan ekonomi di Kabupaten/Kota Provinsi Bali

Berdasarkan hasil analisis dan simpulan di atas maka dapat diajukan beberapa saran Pengeluaran pemerintah sangat diperlukan guna meningkatkan pertumbuhan ekonomi melalui alokasi belanja daerah untuk penyediaan 
infrastruktur. Dengan meningkatnya pertumbuhan ekonomi menandakan perekonomian daerah tersebut semakin baik. Selain itu, pengeluaran pemerintah lebih diarahkan penggunaannya sesuai dengan kebutuhan daerah akan infrastruktur publik sehinggamampu dalam meningkatkan pertumbuhan ekonomi ke depannya agar tujuan dari belanja daerah yaitu mensejahterakan masyarakat dan menurunkan kemiskinan agar tercapai sejalan dengan pertumbuhan ekonomi.Peningkatan investasi yang diperoleh suatu daerah harus diimbangidengan terserapnya tenaga kerja yang ada di setiap daerah, dengan tujuan untuk mengurangi jumlah penduduk miskin dan meningkatkan kesejahteraan masyarakat.

Pentingnya pengalokasian pengeluaran pemerintahserta adanya investasi yang tepat sasaran sangat mempengaruhi pertumbuhan ekonomi yang berdampak pada penurunan kemiskinan, walau belum dapat meningkatkan pertumbuhan ekonomi secara signifikan, dengan adanya pengeluaran pemerintah serta adanya investasi tersebut sangat penting untuk meningkatkan kesejahteraan masyarakat serta menurunkan kemiskinan. Pengeluaran pemerintah dan investasi belum dapat menurunkan tingkat kemiskinan bila belum terjadi pengalokasian yang tepat untuk belanja daerah. Pengeluaran pemerintah yang tinggi serta adanya investasi dari dalam negeri maupun investasi asing belum menunjukan hasil secara langsung untuk meningkatkan pertumbuhan ekonomi serta menurunkan angka kemiskinan, Hal tersebut dikarenakan dalam penyediaan sarana publik yang mendukung pertumbuhan ekonomi belum sesuai dengan potensi daerah tersebut. Walaupun alokasi dana belanja daerah untuk penyediaan fasilitas publik besar, 
namun belum dapat meningkatkan pertumbuhan ekonomi serta menurun angka kemiskinan. Ini dikarenakan banyak kesalahan dalam penyediaan fasilitas publik yang di lihat dari faktor lokasi, fungsi, serta kebutuhan dari masyarakat akan sarana tersebut. Misalnya terminal Mengwi yang sepi menyebabkan penyediaan infrastruktur publik ini tidak efisien dan tidak dapat menunjang pertumbuhan ekonomi serta tidak berdampak pada penurunan kemiskinan.

\section{REFERENSI}

Akudugu, J. A. 2012. Accountability in local government revenue management: who doeswhat?. Journal Information and Knowledge Management, 2(8), 2233.

Al Husna, N. M., \& Yudhistira, H. 2017. Studi Empirik Interaksi Strategis Pemerintah Daerah di Indonesia. Jurnal Ekonomi Kuantitatif Terapan, 10(2), 113-124.

Amalia, R., \& Razak, M. 2015. Pengaruh Pengeluaran Pemerintah Terhadap Kemiskinan Di Provinsi Sulawesi Barat. Jurnal Analisis, 4(2), J. Anal.

Anderson, D. M. 2009. The Effects of Poverty on the Susceptibility to Crime in South Africa. Internasional Journal of Economic, 1(1), 1-12.

Balisacan, A., Pernia, E. M., \& Asra, A. 2003. Revisiting Growth and Poverty in Indonesia. What do Subnational Data Show? Bulletin of Indonesia Economic Studies, 39(3), 329-351.

Budhi, M. K. S. 2013. Analisis Faktor-faktor yang Berpengaruh Terhadap Pengentasan Kemiskinan Di Bali. Jurnal Ekonomi Kuantitatif Terapan, 6(1), $1-6$.

Cooray, A. 2009. Government expendicture, governance and economic growth. Palgrave Journals, 5(1), 401-418.

Coxhead, I., \& Li, M. (2008). Prospects For Skills-Based Export Growth In a Labour-Abudant, Resource-Rich Developing Economy. Bulletin of Indonesian Economic Studies, 44(2), 209-238.

Dariwardani, N. M. I. 2014. Analisis Dinamika Kemiskinan (Poverty Dynamics) di Bali Berdasarkan Data Susenas Panel 2008-2010. Jurnal Ekonomi 
Kuantitatif Terapan, 7(1), $7-15$.

De Fina, R. H. 2002. The Impact Of Unemployment On Alternatif Poverty Measures. Internasional Journal of Economic, 1(2), 1-20.

Fosu, A. K. 2010. Growth, Inequality, and Poverty Reduction in Developing Countries: Recent Global Evidence. CSAE, 7(1), 1-20.

Ikeji, C. C. 2011. Politics of revenue of policy and strategic studies. International Economics Studies, 1(1), 121-136.

Jung, S., Cho, S.-H., \& Roberts, R. K. 2009. Public Expenditure and Poverty Reduction in the Southern United States. Selected Paper prepared for presentation at the Southern Agricultural. Economics Association, 2(1), 1-12.

Kuncoro, H. 2004. Causality Between Total Government Expenduture, Total Tax Revenue and Regional Income in the Case of Manicipalities'/Regency' Local Government in Indonesia. International Economic, 1(1), 1-21.

Marhaeni, A., Sudibia, I. K., Wirathi, I., Rustariyuni, S. D., \& Dewi, N. P. M. 2014. Evaluasi Program-Program Pengentasan Kemiskinan di Provinsi Bali. Jurnal PIRAMIDA, 10(1), 8 - 18.

Mustamin, S. W. A., \& Nurbayani, S. U. 2015. Pengaruh Variabel Ekonomi Makro Terhadap Kemiskinan di Kota Makassar Provinsi Sulawesi Selatan. Jurnal Analisis, 4(2), 165 - 173.

Norton, S. W. 2002. Economic Growth and Provery: In Search of Trickle Down. Cato Journal, 22(2), 263-275.

Ocaya, B., Ruranga, C., \& Kaberuka, W. 2012. Dynamic Relationship between Gross Domestic Product and Domestic Investment in Rwanda. World Journal of Education, 2(6), 1-12.

Osinubi, T. S. 2005. Macroeconometric Analysis Of Growth, Unemployment and Poverty in Nigeria. Pakistan Economic and Social, 12(2), 249-269.

Pateda, Y., Masinambouw, V. A. ., \& Rotinsulu, T. O. 2017. Pengaruh Investasi, Pertumbuhan Ekonomi Dan Pengeluaran Pemerintah Terhadap Tingkat Kemiskinan Di Gorontalo. Jurnal Pembangunan Ekonomi Dan Keuangan Daerah, 19(3), 1-12.

Purnama, N. P. A. M. 2016. Faktor-faktor yang mempengaruhi Kemiskinan di Provinsi Bali. Jurnal PIRAMIDA, 12(1), 101-110.

Putra, W. 2017. Dampak Pengeluaran Pemerintah Terhadap Pertumbuhan Ekonomi dan Indeks Pembangunan Manusia di Perbatasan Indonesia. Jurnal 
Ekonomi, Bisnis Dan Kewirausahaan, 6(2), 120-138.

Sarungu, J. . dan M. E. K. 2013. Analisis Faktor yang Mempengaruhi Investasi di Indonesia Tahun 1990-2010: Metode ECM. Jurnal Ekonomi Kuantitatif Terapan, 1(1), 1-12.

Scott, L. 2002. A Poverty Indicator System For Local Government. Bulletin of Indonesia Economic Studies, 19(4), 499-500.

Seran, S. 2017. Hubungan Antara Pendidikan, Pengangguan dan Pertumbuhan Ekonomi dengan Kemiskinan. Jurnal Ekonomi Kuantitatif Terapan, 10(1), $59-71$.

Sodik, J. 2007. Pengeluaran Pemerintah dan Pertumbuhan Ekonomi Regional: Studi Kasus Data Panel di Indonesia. Jurnal Ekonomi Pembangunan, 12(1), $27-36$.

Yuliarmi, N. N. 2014. Keberdayaan Industri Kerajinan Rumah Tangga Untuk Pengentasan Kemiskinan Di Provinsi Bali (Ditinjau Dari Aspek Modal Sosial Dan Peran Lembaga Adat). Jurnal PIRAMIDA, 10(1), 19 - 28.

Yushkov, A. 2015. Fiscal Decentralization And Regional Economic Growth: Theory, Empirics, And The Russian Experience. Russian Journal of Economics, 1(4), 404-418. 